\title{
イモゾウムシとアリモドキゾウムシのほ場に 打ける発生原因
}

\author{
I．苗による侵入
}

安田 慶次 (沖縄県農業試験場)

\begin{abstract}
Infestation of the sweetpotato weevils (Euscepes postfasciatus FaIRMAIRE, Cylas formicarius Fabricius) in sweetpotato fields. I . Invasion with cuttings. Keiji YASUda (Okinawa Prefectural Agricultural Experiments Station, Naha, Okinawa 903)
\end{abstract}

は じめ に

イモゾウムシ Euscep postfasciatus FAIRMAIRE とアリモ ドキゾウムシ Cylas formicarius FABRICIUS は沖縄県にお けるサッマイモ栽培上最も重要な害虫である。イモゾウ ムシは1947年にハワイ, サイパン等より侵入したものと 考えられており（安里，1950）アアリモドキゾウムシは 1903年以前にすでに沖縄に分布していたものと考芫られ る(名和，1903）。1970年代に打ける有機塩素系の土壌 残効の長い殺虫剤の使用禁止以後, 両種の防除はきわめ て困難となった。現在使用されている薬郕を用いて，植 え付け時の 1 回の土畩処理では, 十分な防除勃果が期待 できない。

そこで両種のより効果的な防除を行う上で重要となる のが，ほ場に打ける発生のメカニズムの解明であると考 えられる。アリモドキゾウムシのほ場における発生原因 として, TALEKARA（1988）は(1) 苗，種いもによる持 込み，(2) 収穕後の残查からの発生，(3) 隣接した他の ほ場からの侵入，(4) アサガオ等の野生寄主植物からの 侵入を挙げている。そこで今回はまず，苗による持ち込 みの可能性について検討を行った。

\section{調 查 方 法}

1）地上䒱の部位別被害調查

1988年10月11日に那覇市，10月13日に読谷村において 苗によってほ場へ持ち込まれる可能性を検討するための 調查を行った。まず，収穕時に茎長 $1.5 \mathrm{~m}$ 以上のサッマ イモの茎を地際部, 地際から30～60 cmの間, 茎の中間部 $30 \mathrm{~cm}$ の間，そして一般に苗として利用する先端部 $30 \mathrm{~cm}$ の 4 か所に分け，それぞれ荎を裂いて被害の有無を調べた。 被害茎及び発見された虫は持ち帰り, 室内で40日間飼育
保管し，羽化した成虫数を種類別に調心゙た。調查した䒱 数は那龩市のほ場の120本, 読谷村の70本であった。調 查に用いたサッマイモの品種はすべて宮譨36号である。

1988年10月10日に読谷村の農家より入手した被害の認 められない苗を通常使用する上部苗 (先端 $40 \mathrm{~cm}$ ), 中部 苗 (中間部 $40 \mathrm{~cm}$ ), 下部苗 (地際より $40 \mathrm{~cm}$ ) に分け，そ れぞれ20本, 計60本を400頭のイモゾウムシの入った容 器に入れ，産卵させた。24時間後に各苗を容器より取り 出し，砂に植え付け，34日後に茥を裂いて幼虫数とその 齢期を調べた。

2) 植え付け後の被害の推移

1988年6月14日にサツマイモの苗300本をほ場に植え 付け, 毎月 1 回30株を掘り取り, 被害荎数, 被害いも率, 被害いも重率を調査した。

3)収穕時に扣ける地下部の部位別被害

1988年10月14日の読谷村で52株，12月15日に那羁市の ほ場で30株について地下部の部位別被害を調べた（第2

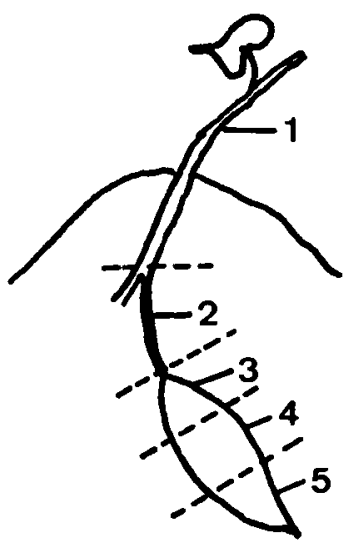

第 1 図収穫時に打ける調查部位 
第 1 表 イモゾウムシによる地上荎の部位別被害状況

\begin{tabular}{|c|c|c|c|c|c|}
\hline \multirow{2}{*}{ 調査月日 } & \multirow{2}{*}{ 調査茎数 } & \multicolumn{4}{|c|}{ 被害茥数（同率\%） } \\
\hline & & 地 際 部 & 地際30～60cm & 中間 $30 \mathrm{~cm}$ & 先端30先端 \\
\hline 10月11日* & 120 & $120(100)$ & $53(44.2)$ & $19(15.8)$ & $0(0)$ \\
\hline 10 月 13 日** & 70 & $70(100)$ & $60(85.7)$ & $38(54.3)$ & $0(0)$ \\
\hline
\end{tabular}

*沖縄本島南部 県農試, **沖縄本島中部 読谷村

第 2 表 イモゾウムシの荃の各部位に詨する被害茎率, 虫数の違い

\begin{tabular}{|c|c|c|c|c|c|c|c|c|c|c|c|}
\hline \multirow{2}{*}{ 荎の部位 } & \multirow{2}{*}{$\begin{array}{l}\text { 調查 } \\
\text { 茎数 }\end{array}$} & \multirow{2}{*}{$\begin{array}{l}\text { 被害 } \\
\text { 茥数 }\end{array}$} & \multirow{2}{*}{$\begin{array}{l}\text { 被害菱 } \\
\text { 率 }\end{array}$} & \multicolumn{2}{|r|}{ 奻 } & \multicolumn{2}{|l|}{ 虫 } & \multirow{2}{*}{ 蛹 } & \multirow{2}{*}{ 成虫 } & \multirow{2}{*}{ 平均龄期 } & \multirow{2}{*}{ 虫数 } \\
\hline & & & & 1 齢 & 2 齢 & 3 齢 & 計 & & & & \\
\hline 上 & 60 & 40 & 66.7 & 12 & 12 & 10 & 34 & 3 & 0 & 2.1 & 37 \\
\hline 中 & 60 & 40 & 66.7 & 8 & 11 & 15 & 34 & 18 & 7 & 3.1 & 59 \\
\hline 下 & 60 & 50 & 83.3 & 1 & 3 & 15 & 19 & 13 & 7 & 3.6 & 39 \\
\hline 上(無産卵) & 60 & 0 & 0.0 & 0 & 0 & 0 & 0 & 0 & 0 & - & 0 \\
\hline
\end{tabular}

* 10 月10日産卵, 10月11日植付, 11月14日調查

四)。地下部での被害は苗の部分(1)，藷梗(2)，株の最大 いもの上部(3), 中部(4), 下部(5)の 5 か所について調査し た。

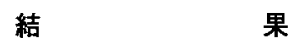

\section{1)地上茥における被害}

地上茎の部分別被害は那䩗市, 読谷村の 2 ほ場とも地 際で100\%の被害率を示し（第 1 表），上部に行くに従い 低下し，䒱の先端部 $30 \mathrm{~cm}$ では虫は認められなかった。さ らにその後の保管調查 (30日間) でも先端部では虫は認 められなかった。なお，保管調查の結果，羽化した成虫 は那羁市でイモゾウムシが 63 頭，アリモドキゾウムシが 2 頭で，読谷村ではそれぞれ，32頭，5頭であった。

次に，イモゾウムシに荎の上部，中部，下部に産卵さ せた後の飼育結果は第 2 表に示した。茎内で虫が発見さ れた被害茎は上部と中部がそれぞれ40本であるのに対し， 下部は50本で $\chi$ 検定の $5 \%$ 水準で上・中部と下部で有 意差が認められた。また，蓄内の虫の平均齢期も上部が 2.1齢，中部が3.1齢，下部が3.6齢と上部に行くに従い 齢期は遅れた。なお，齢期間には分散分析の結果 $1 \%$ 水 準で有意差が認められ，さらに $\mathrm{t}$ 検定の結果上部と下部 で $1 \%$ 水準，上部と中部，中部と下部で $5 \%$ 水準で有意 差が涩められた。茎内の虫数は上部が37頭，中部が59頙， 下部が39頭であったが，茎の各部位間では有意差は認め られなかった。

2）植え付け後のイモゾウムシによる被害の推移 植え付け後の被害の推移は植无付け後 2 か月間までは

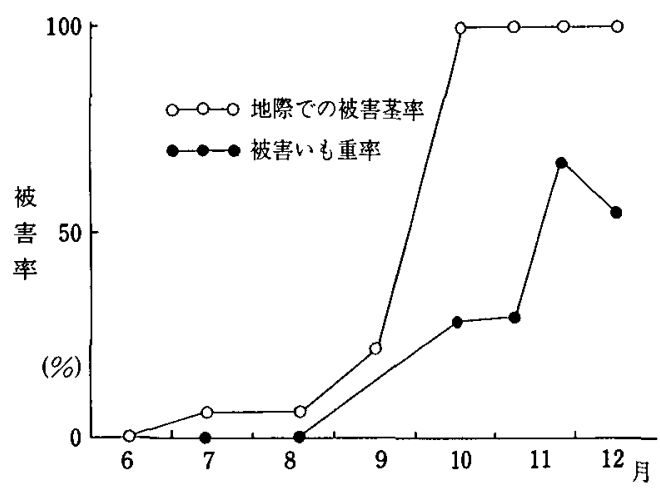

第 2 図 ほ場でのイモゾウムシによる被害の推移

被害䒱率は低く，また，根部の被害も認められなかった (第 1 図)。植え付け後 2 か月以降, 被害荎率㴔速に 増加し，3か月後で $100 \%$ の被害菱率を示した。それに 対し被害いも重率の増加は 4 か月後より認められ，その 增加は比較的緩やかであった。なお，保管調查の結果， 羽化した虫はすべてィモゾウムシであった。

3）収穫時における地下部のイモゾウムシによる被害 状況

収穫時における地下部の被害は植え付け苗の萃にあた る主荎の被害が両ほ場とも100\%を示した(第 3 表)。諳 梗の被害率は比較的低く，いもでは上部の被害が目立っ た。なお，保管調査の結果，羽化した虫はすべてイモゾ ウムシであった。 
第 3 表 収穕時における部位別被害率 $(\%)$

$\mathrm{A}$ ほ場

\begin{tabular}{|c|c|c|c|}
\hline 部 位 & 調查株数 & 被害数 & 被害率 (\%) \\
\hline 1 & 52 & 52 & 100 \\
\hline 2 & 52 & 10 & 19.2 \\
\hline 3 & 52 & 20 & 38.5 \\
\hline 4 & 52 & 12 & 23.1 \\
\hline 5 & 52 & 9 & 17.3 \\
\hline
\end{tabular}

$* 3$ 月23日植付, 10 月14日収穫

考

察

ほ場からサンプリングした菱での被害は地祭部では 100\%の被害率を示したのに対し，菱の中部より先端部 に行くに従い減少した。現在，苗として一般的に用いら れている先端部では，合計190本の調整菱の中から被害 茎は認められず，その後の保管調查でも虫は発見できな かった。地上茎の各部位へ産卵させた場合，部位により 発育に差が認められ，茥の先端部は下部に比較してイモ ゾウムシの幼虫の発育にはあまり適していないと考えら れた。また，荎の中間部で被害が認められる筬所は多く が地面と按している部分である。莣巻ら（1987）はイモ ゾウムシの産卵部位の調查結果から垂直で地際 $0 \sim 1 \mathrm{~cm}$ に集中して産卵すると述べており，これは上記のほ場調 査の結果と一致する。茥の先端部は多くの場合，地表に 接することなく，持ち上がっており，このことも先端部 で産卵が認められない一因と考えられる。

以上のことからイモゾウムシが優占種である地域にお いては，苗によって本種が持ち込まれ，それが発生原因 となる可能性は低いと考えられる。このような地域では 前作の収穫残りのいもや茥等の残查から発生，ほ場外か らの侵入が重要と考えられる。

一方，アリモドキゾウムシについては莣巻ら（1987） は産卵部位の分布は地上の高さに関係なくランダムであ ると述べている。また PROSHLOD (1986) はアメリカの バージン諸島での調査で，アリモドキゾウムシの幼虫は 荃の先端部まで生息していると報告している。このよう にアリモドキゾウムシが比較的多い地域では苗によって 持ち込まれる可能性が高く，さらに检討する必要がある と考えられる。

今回調査したほ場で発生した虫はイモゾウムシが大部 分を占めた。イモゾウムシは第 3 表，第 1 図の結果から， 新しく苗を植え付けたほ場へ侵入，もしくは残查等から
$\mathrm{B}$ ほ場

\begin{tabular}{|c|c|c|c|}
\hline 部 位 & 调査株数 & 被害数 & 被害率 (\%) \\
\hline 1 & 30 & 30 & 100 \\
\hline 2 & $30^{\circ}$ & 18 & 60.0 \\
\hline 3 & 30 & 17 & 56.7 \\
\hline 4 & 30 & 15 & 50.0 \\
\hline 5 & 30 & 12 & 40.0 \\
\hline
\end{tabular}

*6月14日植付，12月15日収穫

羽化，脱出した成虫がまず植え付け苗の地際へ産卵する ものと考えられた。その後，約 4 か月地際の茥を中心に 個体数を増加させ，いもが肥大するにつれ，地下部のい もや譇梗を加害するようになるものと考えられた。

\section{摘要}

地上荎でイモゾウムシの被害を茎の部位別に調查した 結果，地際部では $100 \%$ 被害率を示したのに対し，上 部に行くに従い, 被害䒱率は低下し, 先端部での被害は 認められなかった。また，地上茥の各部位でのイモゾウ ムシの発育状況を検討したとさろ，茎の先端部は下部に 比較して，好適ではないと考えられた。以上の結果から， イモゾウムシが優占種である地域では苗によって本種が 持ち込まれ，それが発生原因となる可能性は低い上考え られた。

アリモドキゾウムシが多い地域では苗によって持ち込 まれる可能性が高く，さらに検討する必要があると考え $ら れ た 。$

ほ場に出現したイモゾウムシの雌成虫は植え付けられ た苗の地際へ産卵し，そこで増殖し，地下部のいもや萻 梗へと加害していくものと考えられた。

\section{引用 文 献}

1）安里清景（1950）甘諳の新害虫イモゾウムシについて 国頭 農報 $2: 8.2$ 2) 荒巻弥弘・吉团 隆・田代 好 (1987) 电美群島におけるアリモドキゾウムシ及びイモゾウムシの生態 調查一産卵状態について一 植防研報 23：67-69. 3）名 和梅吉（1903）形象鼻虫について 昆虫世界 $7: 72$. 4) PROSHOLD, F. I. (1986) Development of weevil populations on Sweet potato in St. Croix. U. S. Virgin Islands. TROPICAL PEST MANAGEMENT, 1986 32:1, 5-10. 5) Talekara, N. S. (1988) How to Control Sweetpotato Weevil : A practical IPM approach, AVRDC 88-292.

（1989年 5 月18日 受領) 